\title{
The Law Enforcement Against Traffic Violations By Minor Children
}

\author{
Wahyu Handono*) and Siti Rodiyah Dwi Istinah ${ }^{* *}$ ) \\ *) Central Java High Court, E-mail: whandono mh36@std.unissula.ac.id \\ ${ }^{* *}$ Faculty of Law Universitas Islam Sultan Agung (UNISSULA) Semarang
}

\begin{abstract}
The purpose of this research is to identify and analyze law enforcement against traffic violations by minors at the Semarang Police Station and to identify and analyze the obstacles to law enforcement against traffic violations by minors at the Semarang Police Station. This study uses a sociological juridical approach, which in this case relates to law enforcement against traffic violations by minors at the Semarang Police Station, with descriptive analytical research specifications. The data used are primary and secondary data which will be analyzed qualitatively. The research problem was analyzed using the theory of justice and the theory of the operation of law. The results of the study conclude that law enforcement against underage traffic violations is through preventive and repressive efforts. Conceptually, the handling of criminal acts in Indonesia is integrated, both within the internal scope of the National Police and within the scope that involves other components outside the National Police. In handling traffic violations by minors, problems arise because they are caused by a lack of legal awareness in the community, lack of traffic discipline, lack of legal socialization, inconsistent law enforcement and selective slashing, aspects of legal culture, and sanctions that are too light.

Keywords: Law Enforcement; Traffic; Minors.
\end{abstract}

\section{Introduction}

The problem of traffic behavior is a common phenomenon in big cities in developing countries. This problem is often associated with the increasing number of urban residents which results in increased activity and density on the highway. Diverse vehicle traffic and the increase in the number of vehicles that are faster than the increase in road infrastructure which results in various traffic problems such as congestion and traffic accidents. Traffic accidents are still a serious problem in developing and developed countries. The death rate according to WHO has reached $1,170,694$ people worldwide. This amount is equivalent to $2.2 \%$ of all deaths in the world and reaches the ninth of the ten causes of death. ${ }^{1}$

Crime can be interpreted criminologically and juridically. Crime in the sense of criminology is a human act that tarnishes the basic norms of society. This is intended as the actions of individuals who violate the rules that live and thrive in society. Juridical crime, i.e. an evil act or evil act in the sense of criminal law means that the crime is formulated in criminal regulations. ${ }^{2}$ For modern countries, the desire to effectively guarantee the rights of citizens and regulate the orderly state administration has encouraged every country to adopt constitutionalism, including

\footnotetext{
${ }^{1}$ http//:id.Wikipedia.org/wiki/Traffic Accidents.

${ }^{2}$ Yusril I A, Bambang Tri Bawono and Ira Alia Maerani, Criminal Investigation of Motorcycle Stealing Goods. Law Development Journal ISSN : 2747-2604 Volume 3 Issue 1, March 2021, (169 - 174). file://C:/Users/win10e/Downloads/14866-35234-1-PB.pdf
} 
legal regulations regarding traffic accidents. ${ }^{3}$ The settlement of criminal cases is carried out through the evidentiary process, namely the prosecution process which is carried out directly in an experiment. ${ }^{4}$ In judicial practice, the process always begins with an arrest, detention, then being prosecuted by the public prosecutor, which ends with a judge's decision. ${ }^{5}$

In Act No. 22 of 2009 concerning Road Traffic and Transportation, all provisions regarding drivers are regulated. Article 1 number 23 of this law stipulates that a driver is "a person who drives a motorized vehicle on a highway who already has a driving license". As for the driver's requirements, it is regulated in Chapter VIII, namely Article 7, in article 80 the same chapter also regulates the classification of driving licenses (SIM) consisting of SIM A, SIM BI, SIM B II, SIM C, and SIM D. 6

In today's era, it is not only adults who commit traffic violations but also school children who are still underage, their level of awareness in traffic is still low, it can be seen from Police data that there are still high numbers of junior high and high school students who violate traffic throughout the year.

The police is a subsystem in the criminal justice system that is sufficient to determine the success and work of the entire system in providing services to the public. ${ }^{7}$ Law enforcement is carried out repressively by law enforcement officers, in the form of imposing sanctions by criminals, in this case carried out by the police, prosecutors, courts, and correctional institutions. Responding to this problem parents should be dominant, in many cases we find it so easy for parents to allow their children to drive vehicles and not be limited to the environment where the child lives. But it is also permissible to bring school vehicles, even though if viewed from any perspective it is not justifiable for a student to bring a vehicle because they are not old enough and do not have a driving license (SIM). Teachers and parents should be firm in addressing this problem that if there are students who do not comply with school regulations, they will be subject to sanctions or need to form a special team with the police to monitor the rules issued by the school. Another concrete action that can be taken is to announce through the media the school students are the most traffic violators.

Indonesia is a legal state where one of the laws, namely criminal law which regulates crimes and violations and punishments for them, is contained in the book of the Criminal Law Act. In addition, delinquency and crimes committed by children

\footnotetext{
${ }^{3}$ Adhe I smail A, Constitutionalism Concept in Implementation of Indonesian State Administration. Jurnal Daulat Hukum Volume 4 Issue 2, June 2021 ISSN: 2614-560X. http://jurnal.unissula.ac.id/index.php/RH/article/view/15737/5567.

${ }^{4}$ Ardito, Y P, Umar Ma'ruf and Aryani Witasari. Implementation of Criminal Action Prosecution Online in Realizing Principle of Fast Prosecution, Simple \& Low Cost, Jurnal Daulat Hukum, Volume 4 Issue 2, June 2021 ISSN: 2614-560X. http://jurnal.unissula.ac.id/index.php/RH/article/view/15737/5567. ${ }^{5}$ Feri, S W, and Arpangi. Settlement Policy of Criminal Actions which Performed by Children through Penal Mediation. Jurnal Daulat Hukum Volume 4 Issue 2, June 2021 ISSN: 2614-560X. http://jurnal.unissula.ac.id/index.php/RH/article/view/15737/5567.

${ }^{6}$ Act No. 22 of 2009 concerning Road Traffic and Transportation.

${ }^{7}$ Nurfita A T, Sri Endah Wahyuningsih and Arpangi. The Police Role in Investigating the Crime of Child Murder as a Result of Infidelity Relationships. Law Development Journal ISSN : 2747-2604 Volume 3 $\left.\begin{array}{llllll}\text { Issue } & 1, & \text { March } & 2021, & (86 & -\end{array}\right)$. http://jurnal.unissula.ac.id/index.php/ldj/article/view/14866/5481.
} 
have been regulated separately in Act No. 11 of 2012 concerning the Juvenile Criminal Justice System, along with the provisions governing the protection of children's rights. The implementation of Act No. 11 of 2012, cannot be separated from the Convention on the Rights of the Child (KHA) and Act No. 17 of 2016 concerning the Second Amendment to Act No. 23 of 2002 concerning Child Protection. Because the purpose of Law No. 11 of 2012 is in order to respect, protect and fulfill the rights of children, especially children in conflict with the law, including children in conflict with the law. Achmad Ali stated that the law is a set of rules or rules that are arranged in a system, which determines what is allowed and what cannot be done by humans as citizens of society in social life, which comes from the community itself or from other sources, which are recognized as valid by the community the highest authority in the community, and is actually enforced by members of the community (as a whole) in their lives, and if these rules are violated, it will give the highest authority the authority to impose external sanctions. After knowing the meaning of the two words above, In general, it can be interpreted that the purpose of law is the direction or target to be achieved by the law in regulating society. In many books on Legal Studies, the discussion of the purpose of law is often separated from the discussion of the function of law.

According to Achmad Ali, things like this are not quite right, because after all the relationship between the purpose of law and the function of law is a very close relationship. The first thing that needs to be known, of course, is the purpose of the law, because only what is the purpose of the law has been determined, we can also determine the functions that the law must carry out in order to achieve its goals. ${ }^{8}$

Thus, there is a need for a change in the sense of revisiting Indonesian criminal law, which so far is still based on the principles and philosophical foundations of foreign nations towards a criminal law system based on the values of the Godhead of YME as the values of the life of the nation and state that are aspired. ${ }^{9}$

The purpose of this study is to find out and analyze law enforcement against traffic violations by minors at the Semarang Police Station and to identify and analyze the obstacles to law enforcement against traffic violations by minors at the Semarang Police Station.

\section{Research Methods}

The approach method used in this study uses a sociological juridical method, namely in addition to using legal principles and principles in reviewing, viewing, and analyzing problems, as they are, ${ }^{10}$ which in this case relates to law enforcement against traffic violations by minors at the Semarang Police Station. The specifications in this study are analytical descriptive. Descriptive research is a

\footnotetext{
${ }^{8}$ Achmad Ali,1997. Menguak Takbir Hukum, Grafindo persada, Jakarta, p. 55

9 Sri Endah Wahyuningsih, 2014, Urgensi Pembaharuan Hukum PIdana Materiel Indonesia Berdasarkan Nilai-Nilai Ketuhanan Yang Maha Esa, Jurnal Pembaharuan Hukum Volume 1 No.1, January-April 2014.

${ }^{10}$ Soerjono Soekanto, 2010, Pengantar Penelitian Hukum, Universitas Indonesia Press, Jakarta, p. 10.
} 
research method that is intended to systematically and accurately describe the facts and characteristics of the research field.

Sources of data used in this study are primary, secondary, and tertiary data sources. Primary data sources are objects that are observed directly in the field and interviewed informants. Primary legal materials consist of: Act No. 22 of 2009 concerning Road Traffic and Transportation. Tertiary legal materials consist of dictionaries, encyclopedias.

The data collection method used to obtain data that has a relationship with the object of research is interviews with resource persons and document review, while the data analysis method used is qualitative data analysis in this study including data reduction, data presentation and conclusions/verification.

\section{Results and Discussion}

\subsection{Law Enforcement Against Traffic Violations by Minors at the Semarang Police Station}

Policy measures to overcome traffic violations must be carried out early in the morning because if they are not carried out from now on, these traffic violations will continue to grow and thrive in society. Likewise, the steps in efforts to overcome these traffic violations must also be implemented from now on. ${ }^{11}$ Because if this is left alone, then traffic violations will occur more often, creating inconvenience, safety threats and causing traffic accidents that can disturb the public.

The handling of traffic violations is generally carried out through preventive and repressive measures. Conceptually, the handling of criminal acts in Indonesia is integrated, both within the internal scope of the National Police and within the scope that involves other components outside the National Police. Thus, the prevention of crimes and violations involving elements outside the National Police with the support and participation of the community at large. ${ }^{12}$

Efforts to overcome criminal acts through preventive efforts, the Police and other law enforcement officers as well as support from community initiatives seek to reduce the frequency of traffic violations, these efforts include: ${ }^{13}$

- Installation of traffic signs

- Brochures

- Counseling

- SIM acquisition

- Raid

There are also several strategies for handling traffic problems carried out by the Police to reduce traffic violations that often occur in the community, including: Traffic Handling Strategy

Efforts to realize road safety are a shared responsibility between road users and competent state apparatus for the handling of roads, both those responsible for

\footnotetext{
11Dewanto, Herpin. 2002. Salah Persepsi karena Rambu-Rambu Lalu Lintas. Artikel : http://kompas.com/kompas.

12 Interview with Ipda Yunanto Dwi Handoko, Head of Subunit Lakalantas Polda Jeteng

${ }^{13}$ Djafairy. 2007. Disiplin Berlalu lintas.http://kompas.com/kompas
} 
the procurement and maintenance of infrastructure and superstructure, road facilities and infrastructure as well as regulation and enforcement of the law. Maintain the situation of Traffic and Traffic on the highway in a directed manner and achieve the expected goals, active participation of road users towards ethics. Courtesy and compliance with applicable laws and regulations are the most important things in order to realize security, safety, order and smooth traffic in accordance with the modern police system placing the community as a subject in maintaining personal safety will have an impact on safety. To realize this, it is necessary to carry out several formulations in the form of 5 (five) handling strategies, in the form of: ${ }^{14}$

\section{- Engineering}

The form of strategy is carried out through a series of observation, research and investigation activities on the factors causing disturbances/obstacles to security, safety, order and smooth traffic as well as providing suggestions in the form of corrective and overcoming steps as well as their development to agencies related to traffic problems.

- Education

All activities that include everything to foster understanding, support and active community participation in efforts to create security, safety, order and smooth traffic with the target of organized communities and unorganized communities so as to raise personal awareness without having to be supervised by officers.

- Enforcement

Are all forms of activities and actions of the Indonesian National Police in the field of traffic so that the law or other traffic laws and regulations are obeyed by all road users in an effort to create a direct Kamseltibcar. Preventive, all efforts and activities to maintain security and public order, maintain the safety of people, objects, the community including providing protection and assistance in particular preventing violations which include traffic regulation, traffic control, traffic control and traffic patrol. Repressive, is a series of actions by investigators to seek and find an event that is suspected of being a criminal act, which includes prosecution of traffic violations and investigation of traffic accidents.

- Encoragment

It can be interpreted: urge / encouragement. That to realize the Traffic and Traffic Security is also influenced by the individual factors of each road user, where the individual Intellectual Intelligence / ability to motivate oneself in order to raise awareness in oneself to be ethical in traffic correctly is needed to make this happen. Growing self-motivation can be influenced by internal factors (one's self-awareness) and external factors (the surrounding environment).

- Emergency Preparedness and response.

Readiness in emergency response in the face of a traffic problem must be a top priority in efforts to handle it, the readiness of all components of traffic stakeholders in the field of traffic always prepare themselves both human

\footnotetext{
14Dwilaksana, Chryshnanda. 2011. Program Sosialisasi Keselamatan. Artikel http://www.satlantassosialisasi-tertib-lalu-lintas-di-sekolah.htm
} 
resources, facilities and infrastructure as well as other things in dealing with situations that may occur, empowering the progress of information and technology is very useful as a road traffic monitor in addition to the presence of officers in the field, in realizing this Emergency Preparedness and response it is necessary to have clear consignments to all stakeholders and in its implementation must be able to work together in an integrated manner in accordance with the SOPs that have been jointly determined. ${ }^{15}$

These five strategies are mapped in the sectors within the police task environment so that it can be seen which agencies are authorized to the relevant sectors including road users, if this strategy can be applied in accordance with the conception that has been formulated, it is expected to be able to realize joint handling efforts where the user community Roads can foster self-defense and the Police and other relevant agencies can carry out their duties professionally and proportionally in carrying out their duties and responsibilities, in other words, ethics, courtesy and compliance with applicable laws and regulations are no longer a "must" that must be met. is an obligation with the implementation of reward and punishment in its implementation, but it becomes a shared "desire" that arises from every individual Polri, related agencies and road users in an effort to realize security, safety, order and smooth traffic on the highway.

\subsection{Obstacles in Enforcement of Criminal Law Against Traffic Violations by Minors in the Future}

Traffic violations today are very concerning, where these violations can cause traffic accidents that can also kill the lives of others. ${ }^{16}$ Factors that may be the cause of traffic and road transportation violations committed by school children, the community and law enforcement officers, the factors causing the accident are:

- Lack of public awareness of the law ${ }^{17}$

One of the causes of rampant traffic violations is the low level of public awareness of the applicable traffic regulations.

Legal awareness means a process of assessing the applicable law or the desired law. ${ }^{18}$ Every society in general has a high legal awareness, but people in general tend to obey the existing regulations due to the sanctions that exist in a statutory regulation, not because of the awareness from within the community.

There are several factors that cause people to obey the law ranging from the following: ${ }^{19}$ Fear of sanctions that will be imposed if the law is violated; To maintain good relations with rulers; To maintain good relations with teammates; Because personal interests are guaranteed by law; Because the law is in accordance with the values adopted, especially the values of order and peace

- $\quad$ Lack of discipline in traffic

\footnotetext{
15 Ibid

16 Interview with AKP Adji Setiawan, SH, MH, Head of Traffic and Traffic Police of Central Java

17 Darmawan, 2002, Taat Berlalu Linta,. http://kompas.com/kompas

${ }^{18}$ Soerjono Soekanto, 2008, Pengantar Penelitian Hukum, Universitas. Indonesia UI-PRESS , Jakarta, p. 33

19 Ibid, p.34
} 
The task of the traffic position must be easier if the discipline of traffic rules should be easier if the discipline of traffic rules can be enforced by all road users. ${ }^{20}$ Discipline in traffic is very much embraced by the community, ${ }^{21}$ Don't be in a hurry to do a job so you ignore the importance of prioritizing safety and neglecting the completeness of driving such as a driving license (SIM) and a vehicle registration certificate (STNK) left at home

- Lack of socialization of the law

Socialization is done so that community members behave as expected without coercion. Efforts to instill an understanding of values and norms to community members are provided through formal and informal channels on a regular basis. ${ }^{22}$

The operation of the law is strongly influenced by several factors, one of which is the community's knowledge of the law. Without sufficient knowledge, society will not behave in accordance with the wishes of the law. By knowing the existence, purpose and benefits of making a law and the sanctions if violated, it is expected that the community will behave according to the expectations and objectives of making the law. ${ }^{23}$

- Inconsistent and selective law enforcement

Law enforcement are those who are directly or indirectly involved in the law enforcement process ${ }^{24}$. The energy used to produce a legal product will be in vain without legal action for the violators. ${ }^{25}$

A law enforcer such as a traffic policeman, for example, must be aware that he is an official who acts as a party serving the interests of the community, therefore every law enforcer on the highway must refuse any kind of gift giving that tends to affect the nature of his decision. ${ }^{26}$ Because the Police of the Republic of Indonesia has the task of fostering the community to increase community participation, legal awareness of the community and the obedience of citizens to laws and regulations. ${ }^{27}$

- Legal Culture Aspect

Legal culture by Friedman is interpreted as attitudes and values related to law and its institutions, both positively and negatively. ${ }^{28}$ If people have positive attitudes and values then the law will be well received, and vice versa.

- Sanctions are too light

${ }^{20}$ Reza. 2008. (SR) Safety Riding adalah usaha meminimalis kecelakaan. Artikel. http://www.hsjbikers.com/forum/view/topic

${ }^{21} \mathrm{Ibid}$

22 Jenis/macam pengendalian sosial dan pengertian pengendalian sosial-pengetahuan sosiologi,http://organisasi.org/jenis-macam-pengendalian-sosial-dan-pengertian-pengendaliansosial pengetahuan-sosiologi

23 Setiyowati, Budaya Hukum Sabuk Keselamatan, http//www.suaramerdeka.com/ 0407/06/opi03.htm,

${ }^{24}$ Soerjono Soekanto, Op.Cit, p. 4

${ }^{25}$ Malik, Abdul. 1981. Pembinaan Kesadaran Hukum dalam Bidang Lalu Lintas, Makalah, Seminar Nasional Kesadaran Hukum Masyarakat Jalan Raya, Fakultas Hukum UII.Yogyakarta, p.10

${ }^{26}$ Soerjono Soekanto, Op.Cit, p. 8

${ }^{27}$ Act No. 2 of 2002 concerning the National Police of the Republic of Indonesia, Article 14 paragraph 1

${ }^{28}$ Setiyowati, Loc.Cit 
Crimes and traffic violations so far are often considered as light crimes by the community, because the sanctions contained in the traffic and road transportation laws are still considered light, namely mostly in the form of fines, so that people do not feel afraid to commit violations in traffic, because with light fines and easy requirements, people will ignore various traffic rules. ${ }^{29}$

\section{Closing}

The conclusion in this study is that law enforcement against traffic violations underage can be done through preventive and repressive efforts. Conceptually, the handling of criminal acts in Indonesia is integrated, both within the internal scope of the National Police and within the scope that involves other components outside the National Police. In handling traffic violations by minors, problems arise because they are caused by a lack of legal awareness in the community, lack of traffic discipline, lack of socialization of the law, inconsistent law enforcement and selective slashing, aspects of legal culture, and sanctions that are too light.

Suggestions in this study are the need for counseling or socialization to school children related to traffic rules so that there are no more cases of traffic violations committed by minors and create an orderly in traffic regarding safety procedures in traffic I hope the judge who handles children's cases in deciding cases against children can see the interests of the child in terms of justice and humanity. The role of parents is very important in the development of children, therefore parents should carry out more supervision by children when driving vehicles and pay attention to all children's activities, especially in the environment around them. In addition, it is very necessary for parents to provide insight to their children about traffic according to applicable procedures and laws.

\section{References}

\section{Journal}

[1] Adhe I smail A, Constitutionalism Concept in Implementation of Indonesian State Administration. Jurnal Daulat Hukum Volume 4 Issue 2, June 2021 ISSN: 2614$560 X$.

[2] Ardito, Y P, Umar Ma'ruf and Aryani Witasari. Implementation of Criminal Action Prosecution Online in Realizing Principle of Fast Prosecution, Simple \& Low Cost, Jurnal Daulat Hukum, Volume 4 Issue 2, June 2021 ISSN: 2614-560X.

[3] Feri, S W, and Arpangi. Settlement Policy of Criminal Actions which Performed by Children through Penal Mediation. Jurnal Daulat Hukum Volume 4 Issue 2, June 2021 ISSN: 2614-560X.

[4] Malik, Abdul. 1981. Pembinaan Kesadaran Hukum dalam Bidang Lalu Lintas, Makalah, National Seminar on Highway Community Legal Awareness, Faculty of Law UII.Yogyakarta.

[5] Nurfita A T, Sri Endah Wahyuningsih and Arpangi. The Police Role in Investigating the Crime of Child Murder as a Result of Infidelity Relationships. Law Development Journal ISSN : 2747-2604 Volume 3 Issue 1, March 2021.

${ }^{29}$ http://forum.vivanews.com/archiv/index.phpt/t-2057.html. 
[6] Sri Endah Wahyuningsih, 2014, Urgensi Pembaharuan Hukum Pidana Materiel Indonesia Berdasarkan Nilai-Nilai Ketuhanan Yang Maha Esa, Jurnal Pembaharuan Hukum Volume 1 No.1, Januari-April 2014.

[7] Yusril I A, Bambang Tri Bawono and Ira Alia Maerani, Criminal Investigation of Motorcycle Stealing Goods. Law Development Journal ISSN : 2747-2604 Volume 3 Issue 1, March 2021, (169 - 174).

\section{Book}

[1] Achmad Ali, 1997. Menguak Takbir Hukum, Grafindo persada, Jakarta.

[2] Soerjono Soekanto, 2008, Pengantar Penelitian Hukum, Universitas. Indonesia UI-PRESS , Jakarta.

[3] Soerjono Soekanto , 2010, Pengantar Penelitian Hukum, Universitas Indonesia Press, Jakarta.

\section{Internet}

[1] Darmawan, 2002, Taat Berlalu Linta,. http://kompas.com/kompas

[2] Dewanto, Herpin. 2002. Salah Persepsi karena Rambu-Rambu Lalu Lintas. Artikel : http://kompas.com/kompas.

[3] Djafairy. 2007. Disiplin Berlalu lintas.http://kompas.com/kompas

[4] Dwilaksana, Chryshnanda. 2011. Program Sosialisasi Keselamatan. Artikel http://www.satlantas-sosialisasi-tertib-lalu-lintas-di-sekolah.html

[5] Jenis/macam pengendalian sosial dan pengertian pengendalian sosialpengetahuan sosiologi,http://organisasi.org/jenis-macam-pengendaliansosial-dan-pengertian-pengendalian-sosial pengetahuan-sosiologi

[6] Reza. 2008. (SR) Safety Riding adalah usaha meminimalis kecelakaan. Artikel. http://www.hsjbikers.com/forum/view/topic

[7] Setiyowati, Budaya Hukum Sabuk Keselamatan, http//www.suaramerdeka.com/0407/06/opi03

[8] http//:id.Wikipedia.org/wiki/KecelakaanLaluLintas

[9] http://forum.vivanews.com/archiv/index.phpt/t-2057.html 